Moisan Perrier, J., D. Kneeshaw, M.-H. St-Laurent, and M.-A. Villard. 2021. Site-infidelity by budworm-linked warblers at the edge of an area defoliated by spruce budworm. Avian Conservation and Ecology 16(1):17. https://doi.org/10.5751/ACE-01847-160117

Copyright (C) 2021 by the author(s). Published here under license by the Resilience Alliance.

\title{
Site-infidelity by budworm-linked warblers at the edge of an area defoliated by spruce budworm
}

\author{
Jeanne Moisan Perrier ${ }^{1}$, Daniel Kneeshaw ${ }^{2}$, Martin-Hugues St-Laurent ${ }^{1}$ and Marc-André Villard ${ }^{1}$ \\ ${ }^{1}$ Département de biologie, chimie et géographie, Centre d'étude de la forêt, Université du Québec à Rimouski, Québec, Canada, \\ ${ }^{2}$ Université du Québec à Montréal
}

\begin{abstract}
Most songbird species show some degree of fidelity to their previous breeding location, especially after successful reproduction. However, species associated with highly dynamic food sources (e.g., outbreaking insects) may have to adopt more flexible strategies. Three species (Tennessee Warbler, Leiothlypis peregrina ; Cape May Warbler, Setophaga tigrina; and Bay-breasted Warbler, $S$. castanea) show strong numerical responses to spruce budworm (Choristoneura fumiferana - SBW) outbreaks. These species, referred to as "budworm-linked warblers", might track SBW larvae through extensive natal dispersal. Then, the superabundance of food during outbreaks would be expected to lead to high breeding productivity which, in turn, should promote breeding site fidelity. Here, we aimed to determine whether budworm-linked warblers were faithful to their previous year's breeding season location and, if so, whether their probability of return was influenced by habitat characteristics such as the density of SBW larvae, stand structure, or landscape structure. We hypothesized that return rate of budworm-linked warblers will be high, as reported in other species of New World warblers, and we predicted that among habitat characteristics, return rate will increase with the density of SBW larvae. We banded 117 budwormlinked warblers (94\% being males) in 75 study plots distributed along a gradient of SBW density and searched for returning individuals within $50 \mathrm{~m}$ of their capture sites using song playbacks. Contrary to our hypothesis, resighting rate was very low $(0-10.5 \%)$. This relative "infidelity" suggests that breeding dispersal of budworm-linked warblers was relatively extensive. Only habitat proportion within an 8$\mathrm{km}$ radius had an important (negative) effect on the probability of resighting Bay-breasted Warbler. Budworm-linked warblers did not exhibit strong site fidelity as adults, but instead performed breeding dispersal movements, presumably to track SBW outbreaks. This strategy may reflect strong spatiotemporal variations in the density SBW larvae.
\end{abstract}

\section{Infidélité au site chez les parulines de tordeuse en bordure d'une zone défoliée par la tordeuse des bourgeons de l'épinette}

RÉSUMÉ. La plupart des espèces de passereaux montrent une fidélité relative à leur site de reproduction, surtout lorsque celle-ci a été fructueuse. Cependant, les espèces associées à des ressources hautement dynamiques dans le temps et dans l'espace (p. ex. les insectes connaissant des phases épidémiques) sont susceptibles d'adopter des stratégies plus flexibles. Trois espèces (Paruline obscure, Leiothlypis peregrina ; Paruline tigrée, Setophaga tigrina ; Paruline à poitrine baie, S. castanea ) montrent une forte réponse numérique aux infestations de tordeuse des bourgeons de l'épinette (Choristoneura fumiferana - TBE). Ces espèces, que l'on appelle "parulines de tordeuse", pourraient en principe suivre les infestations de TBE via leur dispersion natale. Par la suite, la superabondance de nourriture durant les infestations devrait résulter en une productivité élevée, ce qui devrait promouvoir la fidélité au site de nidification. Dans le cadre de cette étude, nous voulions déterminer si les parulines de tordeuse étaient fidèles au site occupé durant la saison de reproduction précédente et, dans un tel cas, si leur probabilité de retour était influencée par les caractéristiques d'habitat, telles que la densité de larves de TBE, la structure des peuplements ou celle du paysage. Nous avons émis l'hypothèse selon laquelle le taux de retour des parulines de tordeuse serait élevé, tel qu'observé chez les autres espèces de parulines du Nouveau-Monde. De plus, nous avons prédit que parmi les caractéristiques d'habitat considérées, le taux de retour augmenterait avec la densité des larves de TBE. Nous avons bagué 117 parulines de tordeuse (incluant $94 \%$ de mâles) dans 75 sites d'étude distribués le long d'un gradient de densité de TBE et nous avons cherché des individus de retour dans un rayon de $50 \mathrm{~m}$ de leur site de capture à l'aide de repasses de vocalisations. Contrairement à notre hypothèse, le taux de détection d'individus de retour a été très faible (0-10.5\%). Cette "infidelité" relative suggère que, chez les parulines de tordeuse, la dispersion des adultes se fait sur des distances relativement grandes. Seule la proportion d'habitat dans un rayon de $8 \mathrm{~km}$ a eu un effet (négatif) important sur la probabilité de détection d'individus de retour, et seulement chez la Paruline à poitrine baie. Les parulines de tordeuse adultes n'ont pas montré une fidélité au site occupé l'année précédente, suggérant qu'elles ont effectué des mouvements de dispersion, possiblement afin de suivre la progression de l'infestation de TBE. Cette stratégie reflète sans doute les importantes variations spatiotemporelles observées dans la densité des larves de TBE.

Key Words: dispersal; defoliating insects; movements; resource tracking; site fidelity 


\section{INTRODUCTION}

Dispersal plays a key role in the survival and reproductive success of many species of animals (Bowler and Benton 2005), as well as in their population dynamics (Clobert et al. 2009). Natal dispersal refers to the movement of individuals between their natal site and their first breeding site, whereas breeding dispersal is the movement between subsequent breeding sites (Greenwood 1980, Greenwood and Harvey 1982. With few exceptions (e.g., Dale et al. 2005), the natal dispersal of songbirds has been shown to be much more extensive, with distances ranging from tens to more than one hundred $\mathrm{km}$ (Tittler et al. 2009), compared to breeding dispersal distances generally $<500 \mathrm{~m}$ (Greenwood and Harvey 1982 and references therein). Prospecting for a future breeding site is energetically expensive (Danchin and Cam 2002, Bonte et al. 2012) and potentially risky, whereas site fidelity allows individuals to develop a familiarity with their territory, procuring advantages such as greater success in dominance interactions, better knowledge of food sources, and refuges from predators, and thus, higher fitness (Piper 2011). Hence, returning to a previous breeding site can be an effective life-history strategy (Greenwood and Harvey 1982, Brown et al. 2017). In fact, individuals are thought to use a "win-stay and lose-switch" strategy, returning to locations where they bred successfully or dispersing after reproductive failure (Greenwood and Harvey 1982, Haas 1998, Hoover 2003, Chalfoun and Martin 2010). In some species, yearlings also show lower site fidelity than older, more experienced individuals (Pyle et al. 2020, but see Burke and Nol 2001), possibly as a result of despotic behaviour by the latter (Sherry and Holmes 1989).

Among songbirds, New World warblers (Parulidae) often exhibit strong breeding site fidelity. For example, in Black-throated Blue Warbler (Setophaga caerulescens), $66 \%$ of males and $46 \%$ of females returned close ( $\sim 150 \mathrm{~m}$ of the centroid) to their previous year's territory (Holmes et al. 2017), whereas American Redstart (S. ruticilla) showed lower return rates (16\% and 39\% for older and yearling males, respectively; $19 \%$ for yearling females), but breeding dispersal was still relatively short (250 m) (Sherry et al. 2020). In the Ovenbird (Seiurus aurocapilla), $69 \%$ of territorial males returned to the 25-ha study plot they occupied the previous year, this proportion reaching $82 \%$ in one particular plot (Haché and Villard 2010). In Canada Warbler (Cardellina canadensis), mean male return rate was $52 \%$ and it was positively associated with shrub density, number of perch trees, and canopy height (Hallworth et al. 2008). Shrub density and number of perch trees were both higher in territories of older males, suggesting that these features are highly valued.

A "win-stay - lose-switch" strategy would be expected to be successful when habitat quality is relatively stable between years (Switzer 1993, Schmidt 2004). In less stable environments, one would expect species to adopt much more flexible strategies allowing them to adjust to year-to-year changes in environmental conditions, such as the abundance of key food resources or the availability of suitable nesting sites. Some species of Parulidae are referred to as "budworm-linked warblers" because they show a strong positive response to outbreaks of the eastern spruce budworm (Choristoneura fumiferana, hereafter SBW) (Venier and Holmes 2010). Indeed, the populations of three species, Tennessee Warbler (Leiothlypis peregrina), Cape May Warbler (S. tigrina), and Bay-breasted Warbler ( $S$. castanea), have been shown to increase rapidly during SBW outbreaks as a result of high fecundity (Venier and Holmes 2010). Increases in budwormlinked warbler abundance as a function of SBW defoliation have been observed at both local and regional scales (Drever et al. 2018, Walker and Taylor 2020). The magnitude of this phenomenon is so important that in California, Patten and Burger (1998) have reported a positive correlation between observations of fall vagrant New World warblers (including all three budworm-linked species) and SBW densities in eastern Canada over a 23-year period. At a regional scale, SBW outbreaks may last from 10 to 20 years, whereas at a local scale, they may last from one to 10 years, depending on forest composition, environmental conditions, and SBW populations (Pureswaran et al. 2016). Such conditions appear much more unstable than those experienced by most other New World warblers, especially because many individuals may immigrate to new SBW epicenters, at least early in a regional outbreak. Yet, no data are available on natal or breeding dispersal in budworm-linked warblers and, therefore, the dispersal strategy adopted by these species is unknown.

Here, we wanted to investigate site fidelity (or lack thereof) in populations of budworm-linked warblers. We hypothesized that most individuals would be faithful to their previous year's breeding location because food is abundant in the early stages of a SBW outbreak and, therefore, most individuals would be expected to breed successfully, a factor that promotes site fidelity (e.g., Thériault et al. 2012). Further, we predicted that SBW density at a given site in year 1 would be positively correlated with the probability of resighting local individuals in year 2 .

\section{METHODS}

\section{Study area}

The study was conducted in the Gaspésie and Bas-Saint-Laurent regions of eastern Québec, Canada (see Moisan Perrier et al. 2021), where a SBW outbreak had been ongoing for 8 years (MFFP 2017a). Surveys were conducted in the balsam fir - yellow birch and balsam fir - white birch forest types. These forest types are dominated by balsam fir (Abies balsamea) and white spruce (Picea glauca), the two main tree hosts of SBW, along with white birch (Betula papyrifera) or yellow birch (B. alleghaniensis). The study area is characterized by extensive plateaus with a maximum elevation of $500 \mathrm{~m}$, dissected by broad valleys (Robitaille and Saucier 1998). We selected 75 study plots along gradients of larval density and according to their stand composition and landscape configuration. We used density estimates derived from ground (SOPFIM 2017a, 2017b) and aerial surveys (MFFP 2017b) to assess SBW density at both local and regional scales and to select study plots spanning a gradient of SBW density. For logistical reasons (mainly access), study plots were clustered in groups of 3 to 6 . Within a cluster, study plots were separated by at least 250 $\mathrm{m}$.

\section{Bird surveys}

From 7 June to 16 July 2017 (hereafter year 1), we captured and banded Tennessee, Cape May, and Bay-breasted Warblers. We used a $6-\mathrm{m}$ mist net and playbacks of conspecific vocalizations to capture individuals. Field protocols were approved by Université de Moncton's Animal Care Committee (CPA-17-06). In some cases, more than one individual was caught at the same 
Table 1. Description of independent variables included in candidate models.

\begin{tabular}{|c|c|c|c|}
\hline Variables & Description & Mean \pm SD & Min-max \\
\hline Basal area of SBW host trees & Plot level basal area of SBW host trees $\left(\mathrm{m}^{2} / \mathrm{ha}\right)$ & $39.71 \pm 9.59$ & $17-59$ \\
\hline Canopy depth & $\begin{array}{l}\text { Distance between the first branch with foliage and the } \\
\text { top of the tree }(\mathrm{m})\end{array}$ & $9.44 \pm 2.33$ & $4.9-16.3$ \\
\hline$\%$ Cumulative defoliation & $\begin{array}{l}\text { Percentage of cumulative defoliation over the } 3 \\
\text { previous years }\end{array}$ & $83.07 \pm 61.81$ & $17.09-211.01$ \\
\hline Elevation & Mean elevation within a $500 \mathrm{~m}$ radius $(\mathrm{m})$ & $399.89 \pm 97.07$ & $230.70-566.69$ \\
\hline Proportion of deciduous trees & $\begin{array}{l}\text { Proportion of basal area represented by deciduous } \\
\text { trees }\end{array}$ & $0.12 \pm 0.12$ & $0-0.44$ \\
\hline Habitat proportion & $\begin{array}{l}\text { Proportion of budworm-linked warbler habitat within } \\
\text { an 8-km radius }\end{array}$ & $0.51 \pm 0.14$ & $0.23-0.75$ \\
\hline SBW abundance & Log (number of spruce budworm larvae/branch tip +1 ) & $1.88 \pm 1.13$ & $0-3.99$ \\
\hline
\end{tabular}

location (12/75 study plots, i.e., $\sim 15 \%$ ). Following capture, birds were fitted with a numbered metal federal leg band on the right leg and aged based on plumage and molt patterns as either yearlings (SY; second calendar year) or older birds (after secondyear; Pyle 1997). One open wing, the open tail and the bird's profile were photographed for verification of aging by Dr Peter Pyle (Institute for Bird Populations), who did not participate in field work.

From 4 to 17 June 2018 (hereafter year 2), we returned to each capture site. We used playbacks of conspecific vocalizations to attract as many individuals as possible of each focal species to determine whether individuals banded in year 1 had returned to the vicinity of their capture site. We searched for $30 \mathrm{~min}$. within a $50-\mathrm{m}$ radius of each capture site using binoculars and we classified each individual of the focal species we saw as banded, unbanded, or unknown (i.e., birds whose right leg could not be seen). Because we only used metal bands, individual identification was only possible upon recapture. Thus, each time a banded bird was detected, we attempted to capture it to read its band number.

\section{Explanatory variables}

Spruce budworm sampling

At each study plot, we sampled SBW larvae using extendable pole pruners in 2017. We clipped two 45-cm long branch tips from the mid-crowns of three SBW host trees (i.e., balsam fir or white spruce) following Morris (1955). Using the software BioSim 11, we predicted the dates at which larvae would reach $4^{\text {th }}$ instar (L4) (Régnière et al. 2017). Thus, we sampled L4 larvae between 14 and 28 June 2017. The sampled branches were also used to estimate cumulative defoliation by summing percentages of defoliation of the three previous years (i.e., 2016, 2015, and 2014). As SBW defoliate almost exclusively the current year's growth, defoliation estimates can be made for current and preceding years based on the number of internodes from the current year (Dorais and Hardy 1976).

\section{Stand and landscape characteristics}

Stand characteristics were estimated within a 50-m radius around the centroid of each study plot. We characterized stand composition and structure using estimates of basal area of SBW host tree species (i.e., balsam fir, white spruce, and black spruce), percentage of basal area represented by deciduous trees, and canopy depth (i.e., distance between the first branch with foliage and the top of the tree). To account for the influence of host tree density on SBW abundance (Bognounou et al. 2017), we included the basal area of SBW host trees in each model.

Budworm-linked warblers are associated with stands dominated by balsam fir and spruces with a minimum canopy height of $7 \mathrm{~m}$ (Baltz and Latta 1998, Venier et al. 2020, Rimmer and McFarland 2020). To account for the influence of such stands on return rate, we classified forest polygons on 1: 20,000 ecoforest maps published by the Ministère des Forêts, de la Faune et des Parcs du Québec (hereafter referred to as MFFP) as "habitat" and "nonhabitat" for budworm-linked warblers. Polygons were then converted into $25 \times 25 \mathrm{~m}$ pixels to calculate habitat amount within the following radii: $100 \mathrm{~m}, 250 \mathrm{~m}, 500 \mathrm{~m}, 1 \mathrm{~km}, 2.5 \mathrm{~km}, 5 \mathrm{~km}, 8$ $\mathrm{km}, 10 \mathrm{~km}, 12 \mathrm{~km}$, and $15 \mathrm{~km}$. Following Lesmerises et al. (2018), we used Akaike's information Criterion corrected for small samples (hereafter $\mathrm{AIC}_{\mathrm{c}}$ ) to select the most appropriate buffer size for each species. Thus, only the buffer size with the lowest $\mathrm{AIC}_{\mathrm{c}}$ was included in model selection for each species. The elevation (in $\mathrm{m}$ ) of each plot was extracted from a digital elevation model. For modelling purposes, we used mean elevation within a 500-m radius of each study plot.

\section{Statistical analyses}

\section{Return rate}

We estimated return rate as a function of the number of banded individuals resighted in year 2 divided by the number of individuals banded in year 1 . We also estimated sampling intensity by dividing the total number of individuals seen in year 2 by the number of individuals banded in year 1 .

Influence of stand and landscape characteristics on breeding site fidelity

To test the prediction of a positive influence of SBW density on the probability of return of budworm-linked warblers, we combined explanatory variables (see Table 1 and the section above for a description) into candidate models (Table 2). The set of candidate models was built hierarchically, i.e., most models included the same SBW-related variables but stand and landscape variables differed. We modelled the probability of return of an individual using binomial generalized linear mixed models (GLMMs) for each warbler species separately, contrasting 
Table 2. Delta AICc and weight of each model used to assess the effects of habitat characteristics on the probability of return of a Bay-breasted Warbler. Independent variables are described in the appendix A. "+" represents an addition and "*” represents an interaction. The most parsimonious model is shown in bold.

\begin{tabular}{|c|c|c|c|c|}
\hline Variable groupings & Model ID & Independent variables & $\Delta \mathrm{AIC}_{\mathrm{c}}$ & weight \\
\hline \multirow[t]{3}{*}{ SBW } & M1 & $\mathrm{SBW}+$ Basal area of SBW host trees & 5.70 & 0.036 \\
\hline & M2 & SBW $+\%$ cumulative defoliation + Basal area of SBW host trees & 8.24 & 0.010 \\
\hline & M3 & SBW $* \%$ cumulative defoliation + Basal area of SBW host trees & 10.89 & 0.003 \\
\hline \multirow{3}{*}{$\begin{array}{l}\text { SBW, stand structure and } \\
\text { composition }\end{array}$} & M4 & M1 + canopy depth $+\%$ deciduous trees & 5.02 & 0.050 \\
\hline & M5 & M2 + canopy depth $+\%$ deciduous trees & 7.81 & 0.012 \\
\hline & M6 & M3 + canopy depth $+\%$ deciduous trees & 10.57 & 0.003 \\
\hline \multirow[t]{4}{*}{ SBW and landscape structure } & M7 & $\mathrm{M} 1+\%$ habitat + elevation & 4.90 & 0.053 \\
\hline & M8 & $\mathrm{M} 2+\%$ habitat + elevation & 7.30 & 0.016 \\
\hline & M9 & M3 \% habitat + elevation & 10.24 & 0.003 \\
\hline & M10 & SBW $* \%$ habitat + elevation & 7.21 & 0.016 \\
\hline Stand structure and composition & M11 & Canopy depth $+\%$ deciduous trees + Basal area of SBW host trees & 3.81 & 0.091 \\
\hline Landscape structure & M12 & $\%$ habitat + elevation & 0.00 & 0.618 \\
\hline Conspecific attraction & M13 & Abundance of BBWA & 3.94 & 0.086 \\
\hline Null model & Null model & & 4.98 & 0.05 \\
\hline
\end{tabular}

capture sites where a banded individual was resighted in year 2 (presence, coded 1) with those where no banded bird was detected (absence, coded 0). The structure of GLMMs made it possible to account for the number of birds banded in each capture site in year 1 , which was included as a random factor in each model. We found no evidence of multicollinearity among independent variables in each model $(\mathrm{VIF}<3.5$; below the threshold proposed by Graham 2003). The most parsimonious model was selected on the basis of its $\mathrm{AIC}_{\mathrm{c}}$ (Burnham and Anderson 2002). All statistical analyses were performed with R 3.5.1 (R CoreTeam 2019).

\section{RESULTS}

\section{Return rate}

In year 1, we captured a total of 117 budworm-linked warblers at 75 study plots, including 32 Tennessee Warblers (15 ASY and 17 SY), 28 Cape May Warblers (12 ASY and 16 SY) and and 57 Baybreasted Warblers (25 ASY and 32 SY). Most (94\%) individuals captured were males.

Of the 7 returning individuals, 6 were Bay-breasted Warblers (Table 3). Bay-breasted Warbler had the highest return rate, at $10.5 \%$, followed by Cape May Warbler. No banded Tennessee Warbler was resighted. Sampling intensity varied from 2.47 for Bay-breasted Warbler to 1.28 for Tennessee Warbler. Overall, we observed two budworm-linked warbler individuals in year 2 for each individual banded the previous year.

Of the 7 returning individuals, only one (a Cape May Warbler male) was recaptured. That individual, aged as ASY in year 1, returned to its capture site in year 2. One banded Bay-breasted Warbler male was seen in year 2 in a study plot where no individual of this species had been banded in year 1 . However, we were unable to recapture this bird. The stand separating these two study plots was partially harvested in year 2 . The closest banding station is located $185 \mathrm{~km}$ away (in Rimouski, Québec, Canada) and, to our knowledge, no other banding study has been conducted in the region. Therefore, we assumed that this individual had returned near its capture site.
Table 3. Proportion of individuals banded in year 1 and returning to the vicinity of their capture site in year 2 .

\begin{tabular}{lcccc}
\hline \hline $\begin{array}{l}\text { Species of } \\
\text { budworm-linked } \\
\text { warbler }\end{array}$ & $\begin{array}{c}\text { Number of } \\
\text { individuals } \\
\text { banded }\end{array}$ & $\begin{array}{c}\text { Number of } \\
\text { individuals } \\
\text { resighted } \\
(\%)\end{array}$ & $\begin{array}{c}\text { Total } \\
\text { number } \\
\text { of } \\
\text { individuals } \\
\text { seen }\end{array}$ & $\begin{array}{c}\text { Sampling } \\
\text { intensity } \\
\text { (seen/banded) }\end{array}$ \\
\hline Bay-breasted & 57 & $6(10.5)$ & 141 & 2.47 \\
Warbler & 28 & $1(3.6)$ & 52 & 1.86 \\
Cape May Warbler & 32 & $0(0)$ & 41 & 1.28 \\
Tennessee Warbler & 117 & $7(6.0)$ & 234 & 2.00 \\
Total & \multicolumn{4}{|l}{} \\
\hline
\end{tabular}

\section{Influence of stand and landscape characteristics on breeding site fidelity}

In our study area, SBW density varied from 0 to 53.5 larvae per branch $(0-3.99 \log ($ budworm/branch +1$))$ and 3-year cumulative defoliation varied from $17.1 \%$ to $211.0 \%$ (Table 1 ). Since spruce budworm larvae only consume the current year's foliage, and conifer branches have 5-7 years of foliage, it is common practice among forest entomologists to add percentages beyond $100 \%$. As an example, a year of $90 \%$ annual defoliation followed by a year of $100 \%$ defoliation of annual foliage is reported by entomologists and pest managers as $190 \%$ cumulative defoliation. Although annual defoliation is measured every year it is cumulative defoliation that is more directly linked to tree vigour and probability of mortality. Even though cumulative defoliation is directly caused by SBW, current year larval density and cumulative defoliation were not significantly correlated in our study (Pearson correlation coefficient $r_{p}=0.36, P=0.23$ ).

Model selection was only conducted for Bay-breasted Warbler, because return rates of Cape May and Tennessee Warbler were too low to assess the influence of habitat characteristics on fidelity to capture sites. Among all stand and landscape characteristics tested, the most parsimonious model included the percentage of habitat within an 8-km radius, as well as elevation, but only the 
first of these variables had an important (negative) effect on Baybreasted Warbler's probability of return (Figure 1, Table 4). In the case of elevation, the $95 \%$ confidence interval included zero. The most parsimonious model yielded good support $(\mathrm{AUC}=0.79$ ). The proportion of habitat within an $8-\mathrm{km}$ radius ranged from 0.23 to 0.75 (mean 0.51 ; Table 1 ).

Table 4. Summary of the most parsimonious model predicting the probability of return of Bay-breasted Warbler. Coefficients whose $95 \%$ CI did not overlap zero are shown in bold.

\begin{tabular}{lcccc}
\hline \hline Variables & $\beta$ & $\begin{array}{c}\text { Standard } \\
\text { error }\end{array}$ & $\begin{array}{c}\text { 95\% CI } \\
\text { [lower: upper] }\end{array}$ & $\begin{array}{c}\text { AUC } \\
\text { value }\end{array}$ \\
\hline $\begin{array}{l}\text { \% habitat within an } \mathbf{8} \mathbf{~ k m} \\
\text { radius }\end{array}$ & $\mathbf{- 1 3 . 3 4}$ & $\mathbf{7 . 9 2}$ & [-36.13: -2.18] & 0.794 \\
\begin{tabular}{l} 
Elevation \\
\hline
\end{tabular} & 1.13 & 1.09 & {$[-0.55: 4.22]$} & \\
\hline
\end{tabular}

Fig. 1. Probability of return of Bay-breasted Warbler as a function of the percentage of habitat within an $8-\mathrm{km}$ radius (see Table 4 for model parameters). The $95 \%$ confidence interval is shown by gray lines and the size of open circles is proportional to the number of overlapping observations.

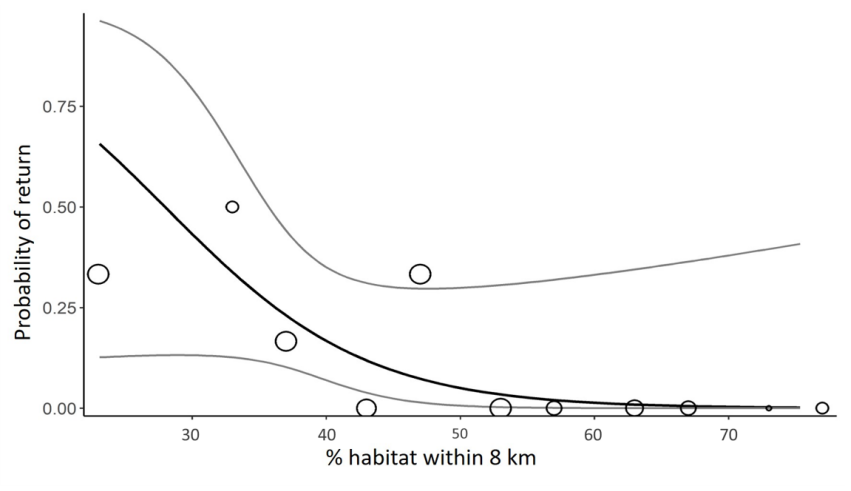

\section{DISCUSSION}

\section{Percent return}

Contrary to our first hypothesis, budworm-linked warblers were rarely resighted in year 2 in the vicinity of their capture sites. Even for the most frequently-captured species (Bay-breasted Warbler), return rate was well below that of other New World warblers, despite similar sample sizes (e.g., Hallworth et al. 2008). In New Brunswick, Canada, most ( $85 \%$ ) Ovenbird returning males held a territory that overlapped the one they occupied the previous year (S. Haché and M.-A. Villard, unpublished data) whereas in New Hampshire, Canada Warbler returning males only dispersed $32 \mathrm{~m}$, on average, between years (Hallworth et al. 2008). Still, it is possible that budworm-linked warblers established a territory beyond the area we surveyed, yet remained within a broader home range occupied the previous year (Whitaker and Warkentin 2010).

It seems unlikely that the dispersal tendency we observed could be attributed to reproductive failure, as the abundance of SBW larvae should have led to high reproductive success in most of our study plots (MacArthur 1958, Venier and Holmes 2010). Instead, the low return rate we observed might reflect resource tracking through breeding dispersal, as a result of local fluctuations in the abundance of SBW larvae. Although we observed high densities of SBW larvae, which would be expected to lead to high productivity and a high degree of site fidelity, our results were not consistent with a "win-stay and lose-switch" strategy. Instead, the patterns we observed (low site fidelity/high breeding dispersal) suggest that budworm-linked warblers have adopted a flexible settlement behaviour in response to an unpredictable of food resource. Indeed, the fact that the current year's larval density was not correlated with cumulative defoliation (i.e., current year plus past years' defoliation) suggests that SBW density varied between years. The progression of a SBW outbreak is not linear, but rather characterized by interannual variability in defoliation and SBW density due to weather and parasitism (Bognounou et al. 2017, Pureswaran et al. 2016, 2018).

\section{Influence of stand and landscape characteristics on breeding site fidelity}

We predicted that the probability of resighting Bay-breasted Warblers would increase with the density of SBW larvae. However, the only tendency we observed was a decrease in resighting probability as the proportion of habitat increased within an $8-\mathrm{km}$ radius. The relationship between resighting probability and habitat proportion was consistently negative across all radii tested. This is consistent with our previouslymentioned interpretation that during a SBW outbreak, Baybreasted Warbler performs breeding dispersal movements at the scale of the local landscape in order to track spatiotemporal shifts in density of SBW larvae. During SBW outbreaks, the quality of nesting territories may change rapidly, as defoliation proceeds. The capacity of experienced Bay-breasted Warblers to track SBW density and settle in high quality habitat might explain why this species is associated with the early stages of SBW outbreaks (Holmes et al. 2009, Germain et al. in press). In the same study area, we found that ASY Bay-breasted Warblers tended to occupy stands supporting higher densities of SBW larvae, with lowcumulative defoliation, whereas SY Bay-breasted Warblers were associated with stands supporting lower densities of SBW (Moisan Perrier et al. 2021). Cape May and Tennessee Warblers showed peaks in abundance only one year prior to defoliation (Germain et al. in press). Hence, they seemed to be associated with later stages of SBW outbreaks than Bay-breasted Warbler.

\section{CONCLUSION}

The relative infidelity of budworm-linked warblers to their previous year's breeding season location compared to that of other species of New World warblers likely reflects more extensive breeding dispersal movements as a consequence of the unpredictability of their food resources. Because we did not search beyond $50 \mathrm{~m}$ of capture sites with playbacks, however, we cannot confirm that individuals dispersed far beyond that distance. A capacity to track densities of SBW larvae would explain why budworm-linked warblers, especially Bay-Breasted Warbler, quickly colonize new SBW epicentres (Holmes et al. 2009, Venier et al. 2009, Moisan Perrier et al. 2021, Germain et al. in press). Hence, budworm-linked warblers may respond both numerically and functionally to SBW outbreaks by increasing their 
reproductive effort, focusing their foraging on budworm larvae, and adopting more flexible dispersal/settlement behaviours through prospection for food patches, as reported in other species associated with unpredictable, irruptive food resources for successful breeding (e.g., Whitaker et al. 1996).

Responses to this article can be read online at: https://www.ace-eco.org/issues/responses.php/1847

\section{Acknowledgments:}

We thank our field assistants, Jessé Roy-Drainville and Amélie Fortier, as well as Peter Pyle and and two anonymous reviewers for their constructive comments on the manuscript. Alexandre DionneLarin helped us with the final formatting of the manuscript. Our field protocol was approved by Universitéde Moncton's Animal Care Committee, protocol CPA-17-06).

\section{LITERATURE CITED}

Baltz M. and Latta S. 2020. Cape May Warbler (Setophaga tigrina), Version 1.0. In P. G. Rodewald, editor. Birds of the World. Cornell Lab of Ornithology, Ithaca, New York, USA https://doi. org/10.2173/bow.camwar.01

Bognounou, F., L. De Grandpré, D. S. Pureswaran and D. Kneeshaw. 2017. Temporal variation in plant neighborhood effects on the defoliation of primary and secondary hosts by an insect pest. Ecosphere 8(3):e01759.10.1002/ecs2.1759 [Online] URL: https://esajournals.onlinelibrary.wiley.com/doi/pdf/10.1002/ ecs2.1759

Bonte, D., H. Van Dyck, J. M. Bullock, A. Coulon, M. Delgado, M. Gibbs, V. Lehouck, E. Matthysen, K. Mustin, M. Saastamoinen, N. Schtickzelle, V. M. Stevens, S. Vandewoestijne, M. Baguette, K. Barton, T. G. Benton, A. Chaput-Bardy, J. Clobert, C. Dytham, T. Hovestadt, C. M. Meier, S. C. F. Palmer, C. Turlure, and J. M. J. Travis. 2012. Costs of dispersal. Biological Reviews 87:290-312. https://doi.org/10.1111/j.1469-185X.2011.00201. $\mathrm{x}$

Bowler, D. E. and T. G. Benton. 2005. Causes and consequences of animal dispersal strategies: Relating individual behaviour to spatial dynamics. Biological Reviews of the Cambridge Philosophical Society 80:205-225. https://doi.org/10.1017/ S1464793104006645

Brown, C. R., E. A. Roche, and M. B. Brown. 2017. Why come back home? Breeding-site fidelity varies with group size and parasite load in a colonial bird. Animal Behaviour 132:167-180. https://dx.doi.org/10.1016\%2Fj.anbehav.2017.08.009

Burke, D., and E. Nol. 2001. Age ratios and return rates of adult male ovenbirds in contiguous and fragmented forests. Journal of Field Ornithology 72:433-438. https://doi.org/10.1648/0273-8570-72.3.433

Burnham, K. P., and D. R. Anderson. 2002. Model Selection and Multimodel Inference: A Practical Information - Theoretic Approach. Springer, New York, New York, United States of America.
Chalfoun, A. D., and T. E. Martin. 2010. Facultative nest patch shifts in response to nest predation risk in the Brewer's sparrow: A "win-stay, lose-switch" strategy? Oecologia 163:885-892. https://doi.org/10.1007/s00442-010-1679-0

Clobert, J., J.-F. Le Galliard, J. Cote, S. Meylan, and M. Massot. 2009. Informed dispersal, heterogeneity in animal dispersal syndromes and the dynamics of spatially structured populations. Ecology Letters 12:197-209. https://doi.org/10.1111/ j.1461-0248.2008.01267.x

Dale, S., A. Lunde, and Ø. Steifetten. 2005. Longer breeding dispersal than natal dispersal in the Ortolan bunting. Behavioral Ecology 16:20-24. https://doi.org/10.1093/beheco/arh129

Danchin, E., and E. Cam. 2002. Can non-breeding be a cost of breeding dispersal? Behavioral Ecology and Sociobiology 51:153-163. https://doi.org/10.1007/s00265-001-0423-5

Dorais, L. G., and Y. J. Hardy. 1976. Méthode d'évaluation de la protection accordée au sapin baumier pas les pulvérisations aériennes contre la tordeuse des bourgeons de l'épinette. Canadian Journal of Forest Research 6:86-92. https://doi.org/10.1139/ x76-011 [In French]

Drever, M. C., D. A. Maclean, A. C. Smith, L. A. Venier, and D. J. H. Sleep. 2018. Cross-scale effects of spruce budworm outbreaks on boreal warblers in eastern Canada. Ecology and Evolution 8 (15):7334-7345. https://doi.org/10.1002/ece3.4244

Germain, M., L. De Grandpré, M. Desrochers, J. Patrick, U. Vepakomma, J.-F. Poulin, D. Kneeshaw, and M.-A. Villard. Insectivorous songbirds as early indicators of future defoliation by spruce budworm. Landscape Ecology in press.

Greenwood, P. J. 1980. Mating systems, philopatry and dispersal in birds and mammals. Animal Behaviour 28:1140-1162. https:// doi.org/10.1016/S0003-3472(80)80103-5

Greenwood, P. J., and P. H. Harvey. 1982. The natal and breeding dispersal of birds. Annual Review of Ecology and Systematics 13:1-21. https://doi.org/10.1146/annurev.es.13.110182.000245

Haas, C. A. 1998. Effects of prior nesting success on site fidelity and breeding dispersal: an experimental approach. Auk 115:929-936. https://doi.org/10.2307/4089511

Haché, S., and M.-A. Villard. 2010. Age-specific response of a migratory bird to an experimental alteration of its habitat. Journal of Animal Ecology 79: 897-905. https://doi.org/10.1111/ j.1365-2656.2010.01694.x

Hallworth, M., A. Ueland, E. Anderson, J. D. Lambert, and L. Reitsma. 2008. Habitat selection and site fidelity of Canada Warblers (Wilsonia canadensis) in central New Hampshire. Auk 125:880-888. https://doi.org/10.1525/auk.2008.07115

Holmes, S.B., Sanders, C.J., Fillman, D., and Welsh, D.A. 2009. Changes in a forest bird community during an outbreak cycle of the spruce budworm in northwestern Ontario. Bird Populations 9:13-28.

Holmes, R. T., S. A. Kaiser, N. L. Rodenhouse, T. S. Sillett, M. S. Webster, P. Pyle, and M. A. Patten. 2017. Black-throated Blue Warbler (Setophaga caerulescens). Version 1.0. In P. G. Rodewald, editor. Birds of the World. Cornell Lab of Ornithology, Ithaca, New York, USA https://doi.org/10.2173/bow.btbwar.01 
Hoover, J. P. 2003. Decision rules for site fidelity in a migratory bird, the Prothonotary Warbler. Ecology 84:416-430. https://doi. org/10.1890/0012-9658(2003)084[0416:DRFSFI]2.0.CO;2

Lesmerises, F., C. J. Johnson, and M.-H. St-Laurent. 2018. Landscape knowledge is an important driver of the fission dynamics of an alpine ungulate. Animal Behaviour 140:39-47. https://doi.org/10.1016/j.anbehav.2018.03.014

MacArthur, R. H. 1958. Population ecology of some warblers of northeastern coniferous forests. Ecology 39:599-619. https://doi. org/10.2307/1931600

MFFP, 2017a. Insectes, maladies et feux dans les forêts du Québec en 2016. Ministère des Forêts, de la Faune et des Parcs, Québec, Canada. [Online] URL: https://mffp.gouv.qc.ca/publications/ forets/fimaq/insectes/bilan2017-p.pdf [In French]

MFFP. 2017b. Aires infestées par la tordeuse des bourgeons de l'épinette au Québec en 2017. Ministère des Forêts, de la Faune et des Parcs, Québec, Canada. [Online] URL: https://mffp.gouv.qc. ca/publications/forets/fimaq/insectes/tordeuse/TBE_2017_P.pdf [In French]

Moisan Perrier, J., D. Kneeshaw, M.-H. St-Laurent, P. Pyle, and M.-A. Villard. 2021. Budworm-linked warblers as early indicators of defoliation by spruce budworm: a field study. Ecological Indicators 125:107543. https://doi.org/10.1016/j.ecolind.2021.107543

Morris, R. 1955. The development of sampling techniques for forest insect defoliators, with particular reference to the spruce budworm. Canadian Journal of Zoology 33:225-294. https://doi. org/10.1139/z55-015

Newton, I. 2001. Causes and consequences of breeding dispersal in the sparrowhawk Accipiter nisus. Ardea 89: 143-154.

Patten, M. A., and J. C. Burger. 1998. Spruce budworm outbreaks and the incidence of vagrancy in eastern North American wood warblers. Canadian Journal of Zoology 76:433-439. https://doi. org/10.1139/z97-213

Piper, W. H. 2011. Making habitat selection more "familiar": A review. Behavioral Ecology and Sociobiology 65:1329-1351. https://doi.org/10.1007/s00265-011-1195-1

Pureswaran, D.S., Johns, R., Heard, S. B and D. Quiring. 2016. Paradigms in eastern spruce budworm (Lepidoptera Torticidea) population ecology : a century of debate. Environmental Entomology 45 (6):1333-1342. https://doi.org/10.1093/ee/nvw103

Pyle, P., K. R. Foster, C. M. Godwin, D. R. Kaschube, and J. F. Sarocco. 2020. Yearling proportion correlates with habitat structure in a boreal forest landbird community. PeerJ 8:e8898. https://doi.org/10.7717/peerj.8898

Pyle, P. 1997. Identification Guide to North American Birds, Part1: Columbidae to Ploceidae. Slate Creek Press, Bolinas, California, United States of America.

R CoreTeam. 2019. R: A language and environment for statistical computing. R Foundation for Statistical Computing. Vienna, Austria. [Online] URL: https://www.r-project.org/

Régnière, J., Saint-Amant, R., Béchard, A., and Moutaoufik, A. 2017. BioSIM 11 User's Manual. Canadian Forest Service, Laurentian Forestry Centre, Quebec City, Quebec, Canada.
Rimmer, C. C., and K. P. McFarland. 2020. Tennessee Warbler (Leiothlypis peregrina), Version 1.0. In A. F. Poole, editor. Birds of the World. Cornell Lab of Ornithology, Ithaca, New York, USA https://doi.org/10.2173/bow.tenwar.01

Robitaille, A., and J.-P. Saucier. 1998. Paysages régionaux du Québec méridional. Publications du Québec. Québec, Canada. [In French]

Schmidt, K. A. 2004. Site fidelity in temporally correlated environments enhances population persistence. Ecology Letters 7:176-184. https://doi.org/10.1111/j.1461-0248.2003.00565.x

Sherry, T. W., R. T. Holmes, P. Pyle, and M. A. Patten. 2020. American Redstart (Setophaga ruticilla). Version 1.0. In P. G. Rodewald, editor. Birds of the World. Cornell Lab of Ornithology, Ithaca, New York, USA https://doi.org/10.2173/bow.amered.01

Sherry, T. W., R. T. Holmes. 1989. Age-specific social-dominance affects habitat use by breeding American Redstarts (Setophaga ruticilla) - a removal experiment. Behavioral Ecology and Sociobiology 25:327-333. https://doi.org/10.1007/BF00302990

SOPFIM. 2017a. Tordeuse des bourgeons de l'épinette 2017Niveaux de population / dommage annuels anticipés. GaspésieÎles-de-la-Madeleine. Société de la protection des forêts contre les insectes et maladies. [In French]

SOPFIM. 2017b. Tordeuse des bourgeons de l'épinette 2017 Niveaux de population / dommage annuels anticipés. Bas-SaintLaurent. Société de la protection des forêts contre les insectes et maladies [In French]

Switzer, P. V. 1993. Site fidelity in predictable and unpredictable habitats. Evolutionary Ecology 7:533-555. https://doi.org/10.1007/ BF01237820

Thériault, S., M.-A.Villard, and S. Haché. 2012. Habitat selection in site-faithful ovenbirds and recruits in the absence of experimental attraction. Behavioral Ecology 23:1289-1295. https://doi.org/10.1093/beheco/ars119

Tittler, R., M.-A.Villard, and L. Fahrig. 2009. How far do songbirds disperse? Ecography 32:1051-1061. https://doi. org/10.1111/j.1600-0587.2009.05680.x

Venier, L. A., and S. B. Holmes. 2010. A review of the interaction between forest birds and eastern spruce budworm. Environmental Reviews 18:191-207. https://doi.org/10.1139/a10-009

Venier, L. A., S. B. Holmes, and J. M. Williams. 2020. Bay-breasted Warbler (Setophaga castanea), Version 1.0. In A. F. Poole, editor. Birds of the World. Cornell Lab of Ornithology, Ithaca, New York, USA https://doi.org/10.2173/bow.babwar.01

Venier, L. A., J. L. Pearce, D. R. Fillman, D. K. McNicol, and D. A.Welsh. 2009. Effects of Spruce budworm (Choristoneura fumiferana (Clem.)) outbreaks on boreal mixed-wood bird communities. Avian Conservation and Ecology 4(1):3. https://doi. org/10.5751/ace-00296-040103

Walker, J. and P. D. Taylor. 2020. Evaluating the efficacy of eBird data for modeling historical population trajectories of North American birds and for monitoring populations of boreal and Arctic breeding species. Avian Conservation and Ecology 15(2):10. https://doi.org/10.5751/ACE-01671-150210 
Whitaker, D. M., and I. G. Warkentin. 2010. Spatial ecology of migratory passerines on temperate and boreal forest breeding grounds. Auk 127:471-484. https://doi.org/10.1525/auk.2010.127.3.471

Whitaker, D. M., W. A. Montevecchi, and J. W. Gosse. 1996. Breeding season irruptions of Rough-legged Hawks (Buteo lagopus) on insular Newfoundland. Arctic 49:306-310. https://doi. org/10.14430/arctic1205

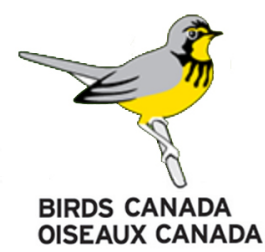

